Article (refereed) - postprint

Monteith, Donald T.; Henrys, Peter A.; Evans, Chris D.; Malcolm, lain;

Shilland, Ewan M.; Pereira, M.G. 2015. Spatial controls on dissolved

organic carbon in upland waters inferred from a simple statistical model.

Biogeochemistry, 123 (3). 363-377. 10.1007/s10533-015-0071-x

(C) Springer International Publishing Switzerland 2015

This version available http://nora.nerc.ac.uk/509703/

NERC has developed NORA to enable users to access research outputs wholly or partially funded by NERC. Copyright and other rights for material on this site are retained by the rights owners. Users should read the terms and conditions of use of this material at

http://nora.nerc.ac.uk/policies.html\#access

This document is the author's final manuscript version of the journal article, incorporating any revisions agreed during the peer review process. There may be differences between this and the publisher's version. You are advised to consult the publisher's version if you wish to cite from this article.

The final publication is available at Springer via http://dx.doi.org/10.1007/s10533-015-0071-x

Contact CEH NORA team at noraceh@ceh.ac.uk

The NERC and CEH trademarks and logos ('the Trademarks') are registered trademarks of NERC in the UK and other countries, and may not be used without the prior written consent of the Trademark owner. 


\section{SPATIAL CONTROLS ON DISSOLVED ORGANIC CARBON IN UPLAND WATERS INFERRED FROM A SIMPLE STATISTICAL MODEL}

Running title: Spatial controls on dissolved organic carbon

Donald T Monteith ${ }^{1}$, Peter A Henrys ${ }^{1}$, Chris D Evans ${ }^{2}$, Iain Malcolm³ ${ }^{3}$ Ewan M Shilland ${ }^{4}$, M. Glória Pereira ${ }^{1}$

${ }^{1}$ Centre for Ecology and Hydrology, Lancaster Environment Centre, Library Avenue, Bailrigg, Lancaster LA1 4AP, U.K;

${ }^{2}$ Centre for Ecology and Hydrology, Environment Centre Wales, Deiniol Road, Bangor, LL57 2UW, United Kingdom.

${ }^{3}$ Marine Scotland Freshwater Laboratory, Faskally, Pitlochry, Perthshire, PH165LB, Scotland.

${ }^{4}$ Environmental Change Research Centre, University College London, Gower Street, London WC1E 6BT, UK.

Correspondence: D. T. Monteith

e-mail:donm@ceh.ac.uk

Keywords: Dissolved Organic Carbon, Dissolved Organic Matter, upland waters, acidification, recovery, climate change, land use.

Paper type: Research article

Published in Biogeochemistry: DOI 10.1007/s10533-015-0071-x 
Abstract

Dissolved organic carbon (DOC) concentrations in upland surface waters in many northern hemisphere industrialised regions are at their highest in living memory, provoking debate over their "naturalness". Because of the implications for drinking water treatment and supply there is increasing interest in the potential for mitigation through local land management, and for forecasting the likely impact of environmental change. However, the dominant controls on DOC production remain unresolved, hindering the establishment of appropriate reference levels for specific locations. Here we demonstrate that spatial variation in long-term average DOC levels draining upland UK catchments is highly predictable using a simple multiple logistic regression model comprising variables representing wetland soil cover, rainfall, altitude, catchment sensitivity to acidification, and current acid deposition. A negative relationship was observed between DOC concentration and altitude that, fro catchments dominated by organo-mineral soils, is plausibly explained by the combined effects of changing net primary production and temperature-dependent decomposition. However, the magnitude of the altitude effect was considerably greater for catchments with a high proportion of wetland cover, suggesting that additional controls influence these sites such as impeded respiratory loss of carbon in wet soils and/or an increased susceptibility to water level drawdown at lower altitudes. The model suggests 1) that continuing reductions in sulphur deposition on acid sensitive organo-mineral soils, will drive further significant increases in DOC and, 2) given the differences in the magnitude of the observed altitudeDOC relationships, that DOC production from catchments with peat-dominated soils may be more sensitive to climate change than those dominated by mineral soils. However, given that mechanisms remain unclear, the latter warrants further investigation. 


\section{$\underline{\text { Introduction }}$}

Surface waters draining organic-rich soils (deep peats, and 'organo-mineral' soils with either a peaty or organic-matter rich upper horizon) typically contain significant amounts of dissolved organic matter (DOM), commonly quantified in terms of dissolved organic carbon (DOC) concentration. A contributor to both organic acidity and water "colour", DOM in these systems is derived predominantly from allocthonous organic matter, originating largely from decomposing vegetation and plant root exudates (Thurman 1985).

Processes determining the terrestrial production and fluvial export of DOM from boreal landscapes are receiving mounting attention, reflecting growing recognition of the importance of DOC in the global carbon cycle (Bauer and Bianchi 2011) and wider soil biochemical processes (Taylor and Townsend 2010). More immediate economic concerns have arisen in regions such as the northern and western UK, parts of Scandinavia, and the Czech Republic (Oulehle and Hruska 2009), where surface waters supply drinking water to the majority of the population. Here, and elsewhere in northern Europe and North America, DOC concentrations have been rising over the last quarter century or more (Monteith et al. 2007; Skjelkvåle et al. 2005).

There is a widely held perception in the UK and elsewhere that current DOC concentrations in upland surface waters used for water supply are unnaturally high. In part this stems from observations of rising levels of DOC in waters draining catchments that have been significantly modified by human activities. In the UK, peat erosion is widespread in catchments used for water supply. This degradation has been attributed variously to loss of bryophyte cover through effects of air pollution (e.g. Ferguson and Lee (1983)) the effects of drainage schemes (Holden et al. 2007), over-grazing by sheep (Evans 1997) and excessive burning in the course of grouse moor management (Yallop and Clutterbuck 2009) - problems that also concern stakeholders tasked with conserving upland biodiversity. However, it is also clear that DOC concentrations vary markedly across upland catchments as a result of intrinsic geophysical factors. For example, concentrations tend to be higher in catchments dominated by peats, regardless of the extent of physical degradation (Hope et al. 1994).

Furthermore, upland soils have been shown to be biogeochemically sensitive to the influences of atmospheric pollutants, and particularly the acidifying effects of sulphur, nitrogen and hydrochloric acid (Evans et al. 
2012; Evans et al. 2011). Over the past two decades, levels of acid deposition in the UK have fallen substantially in response to an international drive to control acidic emissions (Curtis and Simpson 2014) and overall, sulphur deposition in the UK is estimated to have declined by $80 \%$ from 1986 to 2006 (RoTAP 2012). DOC concentrations in remote surface waters have been observed to change in proportion to these reductions across the industrialised northern hemisphere (Monteith et al. 2007) in an apparent solubilitydriven response to declining soil acidity (Ekstrom et al. 2011; Evans et al. 2012) and/or declining soil water ionic strength (Hruška et al. 2009). It is therefore feasible that recent increases in DOC in some areas represent a return toward pre-industrial (i.e. pre-acidification) conditions. There are very few long term records internationally of sufficient duration to chart DOC responses to rising and, more recently, falling acid deposition. However, a century long record of transparency in a Bohemian lake (Vrba et al. 2003), and a 420 nm absorbance record from Alsterälven in southern Sweden that reaches back to the 1960s (Forsberg 1992), both lend support for this "recovery" hypothesis.

Alternatively, deposition-induced increases in solubility may be leading to unprecedented levels of DOC if other factors favouring increased DOC leaching have also changed since the pre-industrial period. For example, it has been suggested that net primary productivity (NPP), and hence the supply of potentially soluble organic matter, is now higher than in pre-industrial times as a result of the accumulation of atmospherically deposited reactive nitrogen in these catchments (Rowe et al. 2014; Tipping et al. 2012). Various studies have also suggested that either total decomposition rates, or the proportion of decomposed organic matter leached as DOC rather than respired as $\mathrm{CO}_{2}$, may have increased due to climatic and/or management changes (Freeman et al. 2001).

Increasingly, physical catchment-level intervention is being proposed to stabilise, or even reverse, inputs of DOC from physically degraded catchments to the water supply system (e.g. SCAMP (2013). However, there is currently no statistical or conceptual framework for deriving expected DOC concentrations for waters in a particular environmental setting, and therefore no way of gauging the extent to which observations may be deviating from those expected in the absence of local impacts. Hydrochemical records rarely, if ever, reach back prior to such disturbances, while palaeolimnological DOC reconstruction techniques that have the 
potential to predict historical concentrations in lakes (e.g. Rosén et al. (2011)) are still under development and cannot, in any case, be applied to running waters.

If spatial variation in DOC concentrations in surface waters draining largely physically undisturbed catchments could be modelled accurately from a set of variables representing dominant controls, this would not only guide the assessment of the DOC status of other sites of concern (e.g. to water authorities), but would also provide long-term baselines for these sites against which long term trends and shorter term variation could subsequently be modelled. The practice of defining long-term climatic baselines is already standard practice in the field of modelling and prediction of climate change. Finally, the structure of such a model should provide a clearer understanding of the relative roles of physical and biogeochemical factors in determining spatial variation in DOC and, consequently, in the prediction of future DOC trajectories in view of anticipated future climate change and further reductions in acid deposition.

In this paper we describe the development and structure of a simple multiple logistic regression model that explains spatial variation in long-term (20 year mean; 1992-2011) DOC concentrations for an intensively and continuously monitored set of 21 upland lakes and streams across the UK. By using as long a period as the dataset allowed we sought to minimise the effect of short-term, site-specific, variation in DOC that could otherwise cloud the spatial signal, thus providing the most robust baseline possible for future dynamic modelling. However, since most sites show long term changes in DOC that have slowed in recent years, we also describe an identically parameterised, although slightly poorer fitting model, based on a more contemporary dataset (2009-2013), that is arguably of more immediate value in the assessment of DOC status of other recently monitored sites. Finally, focussing on the structure of the most parsimonious (20 year mean) model, we consider the processes that may govern spatial variability in DOC and the potential value of the model as a predictive tool.

\section{Materials and methods}

Study sites 
Our study was focussed primarily on sites from the UK Upland Waters Network (UWMN) (Table 1). The UWMN includes the outflows from small lakes (ranging in surface area from 2-114 ha, in volume from 3.6 x $10^{4}-7.4 \times 10^{6} \mathrm{~m}^{3}$ and in residence time from around 2 weeks to 6 months) and streams (first or second order) from many regions of the UK uplands (Battarbee et al. 2014). The UWMN is an expansion of the former UK Acid Waters Monitoring Network, which was established to assess the efficacy of regional reductions in acid pollutants (see for example, Monteith and Evans (2005)). AWMN sites were selected originally on the criteria of low geological acid-buffering capacity and the absence of marked local catchment interference or point source contamination that might otherwise complicate acidification/recovery signals. The main exception to the latter criterion was the selection of a subset of sites with significant conifer plantation forestry. The remaining sites were either subject to low-intensity grazing (mainly by sheep or deer) which maintains a grassland or heathland cover, or were located above the natural tree line. Two southern English UWMN sites were excluded from our analysis on the grounds that their catchments were not glaciated in the last glacial period and active sulphur cycling in B horizons distorts the strong link between sulphur deposition and sulphate concentration in runoff that is seen across the rest of the network (Cooper 2005). In order to extend the geochemical gradient into more strongly buffered systems the dataset also included the Environmental Change Network (ECN) stream site, the Trout Beck (northern Pennines) that drains blanket peat overlying carboniferous limestone.

\section{Water sampling and analysis}

Water chemistry samples from the outflow of each lake were collected usually in the first week of March, June, September and December. The UWMN streams were sampled every month in order to better capture the larger hydrochemical variation of these systems. The second order ECN Troutbeck stream was sampled weekly. All water samples were filtered using $0.45 \mu \mathrm{m}$ cellulose nitrate filters and analysed for DOC using a TOC analyser by first acidifying samples to purge inorganic carbon, followed by high temperature combustion and spectrometric analysis of the resulting $\mathrm{CO}_{2}$. Acid anions were analysed by ion chromatography, and base cations using an Inductively Coupled Plasma Mass Spectrometer or Optical Emission Spectrometer (i.e. ICP-MS or ICP-OES). The laboratories participating in the UWMN operate a range of quality control procedures (Gardner 2008) and participate in an annual international AQC 
assessment provided by the UNECE International Cooperative Programme on the Assessment of Acidification of Rivers and Lakes (or ICP Waters Network).

\section{Physical data}

Data for a number of mechanistically plausible metrics or surrogates for potential process drivers were compiled to predict spatial variability in DOC, several representing factors that have been linked to DOC in previous spatial assessments (see Supplementary Table 1 for full list and explanation of the derivation of the soils data).

Area-weighted mean catchment altitude (ALT) was determined from a digital terrain model. Site-specific daily precipitation data were obtained for the $1 \mathrm{~km}$ square most central to each catchment from the NERC Centre for Ecology and Hydrology’s hydrological CHESS (Climate, Hydrological and Ecological research Support System) dataset, which is based on interpolated data from the UK Met Office's network of meteorological stations. These data were available at the time of analysis up to the end of 2007 only, so data for the period 1988-2007 were used to provide a 20 year annual mean. Precipitation was then corrected for evaporative loss (to provide effective precipitation $\left(\mathrm{P}_{\mathrm{E}}\right)$ ) by subtracting the UK Met Office's $1 \mathrm{~km}$ square resolution Standard-period Average Annual Rainfall (SAAR) evaporation estimate (representing the period 1961-1990).

Due to local variation in topography, $1 \mathrm{~km}$ interpolated air temperature data were unsuitable for determining air temperatures for the mid-altitude points of catchments. Mean annual air temperature (MAT) for each site was therefore estimated using a linear model describing the relationship between mean annual temperature, altitude and latitude for the 12 meteorological stations on the UK Environmental Change Network (ECN) which span gradients of altitude and latitude of $100-700 \mathrm{~m}$ and $50.8-57.1^{\circ} \mathrm{N}$ respectively; i.e.

$\operatorname{MAT}\left({ }^{\circ} \mathrm{C}\right)=28.5-(0.343 \times$ latitude $)-(0.00612 \times$ ALT $) \quad\left(\mathrm{R}^{2}=0.97\right)$

- where latitude is in degrees North, and ALT in metres above sea level (masl). 
Soil data were derived from the UK FAB database which is based on extracted shapefiles from the Soil Survey and Land Research Centre, Macaulay Land Use Research Institute, and Department of Environment Northern Ireland databases (Curtis pers. comm.). Soil map units were converted to the "Institute of Terrestrial Ecology Generic classes”. Data were represented as percentage cover of each catchment for a range of soil types, and included the sum of proportions of peat and peaty gley soils (PPPG) to represent wetland soil coverage.

Non-marine concentrations of calcium and magnesium were calculated as an indicator of catchment sensitivity to acidification, using the difference between long-term mean concentrations of these ions and a hypothetical marine fraction based on long-term mean chloride concentration (cf. Evans et al. (2001). We also calculated long term mean sulphate $\left[\mathrm{SO}_{4}\right]$, nitrate and chloride concentration to represent the contribution of these acid anions in runoff.

Data representing spatial variation in the deposition of oxidised sulphur and oxidised and reduced $\mathrm{N}$ for the period 2001-2003 were obtained from 5km gridded estimates provided by the NERC Centre for Ecology and Hydrology and used to inform national air quality policy (RoTAP 2012). These were determined from estimates of dry and wet deposition derived from measurements of gas concentrations and of ion concentrations in rainfall respectively. Deposition estimates were modelled using the same procedures as for the UK deposition estimates (RoTAP 2012; Smith and Fowler 2001; Smith et al. 2000), and include a vegetation canopy resistance model to estimate gas and particle deposition and an orographic enhancement for wet deposition.

\section{Data Analysis}

To accommodate a sub-set of UWMN sites for which monitoring started later than 1988, 20 year site means for DOC and other hydrochemical variables (see below) were derived for the period April 1992 to March 2011. While this period is out of sync with the 20 year precipitation estimates, we assumed between-site variation would be much greater than temporal variation in the 20 year means and that this discrepancy would therefore be unlikely to weaken the predictive power of this potential explanatory variable. Monitoring of 
Loch Coire nan Arr was terminated at the end of 2007, but we established that there were only marginal differences in mean DOC concentrations for the period 1992-2007 compared to 1992-2011 ( on average concentrations for the former period were $96 \%$ of those for the latter) and we therefore decided to keep this site in the dataset. We used the product of DOC and $\mathrm{P}_{\mathrm{E}}$ to provide an approximation for DOC flux.

Exploratory data analysis involved inspection of a series of scatter plots and Pearson correlation coefficients comparing both mean annual DOC and mean annual DOC flux (i.e. DOC $x \mathrm{P}_{\mathrm{E}}$ ) with a broad range of potentially explanatory variables (correlation coefficients provided in Supplementary Table 2). Decisions on whether or not to log transform each variable were based on the structure of between-site variation. A range of candidate multiple logistic regression models, chosen on the basis of backward elimination to minimise the Akaike Information Criterion (AIC), were then produced to explain spatial variation in mean annual DOC using subsets of the variables that either showed strong individual relationships with either DOC variables, and/or have previously been identified in either spatial or temporal studies as being potentially influential (see Discussion). The latter included variables representing acid deposition and catchment sensitivity to acidification on the basis of observations by Monteith et al. (2007).

The transferability of the most parsimonious, or "final", spatial model, based on the lowest AIC, was tested both internally and externally. First, we carried out leave-one-out cross validation of the UWMN/ECN dataset. Second, we compiled the necessary mean DOC and explanatory data for an independent set of lake and streams sites. There are very few alternative multi-decadal hydrochemical records for UK upland surface waters of sufficient analytical quality available for this purpose. We therefore assembled a dataset for a range of sites that were all sampled at least quarterly (lakes) or monthly (streams) within one year between the period 1993 and 1997, and analysed for DOC and other hydrochemical variables using analytical methods appropriate for dilute waters (Gardner 2008). Effective precipitation for these sites was determined using SAAR long-term (1961-1990) average precipitation and evaporation data.

While we deliberately used the longest time series available (i.e. 1992-2011) to develop the most robust spatial model of long-term mean concentrations, further modelling of superimposed long-term trends and 
shorter-term variability is beyond the scope of this paper. As DOC concentrations have increased over much of the time period represented, contemporary levels across the UK uplands are likely to exceed those predicted on the basis of modelled 20 year means. We therefore repeated the modelling approach using the same parameters on a five year dataset covering the period 2009-2013, during which concentrations have been relatively stable, in order to provide a more contemporary predictive tool. In this case Loch Coire nan Arr was replaced with the neighbouring site Loch Coire Fionnaraich which replaced the former site in 2008. 


\section{$\underline{\text { Results and Discussion }}$}

\section{Exploratory analysis}

Long-term mean DOC in our dataset ranged from $1.6 \mathrm{mg} \mathrm{L}^{-1}$ at the second highest site with a catchment dominated by peat ranker soils (Scoat Tarn, northern England), to $13.9 \mathrm{mg} \mathrm{L}^{-1}$ at a relatively low elevation peatland site (Beagh's Burn, Northern Ireland) (Table 1). Mean DOC draining the highest altitude site, Lochnagar (northeast Scotland) was slightly higher $\left(0.2 \mathrm{mg} \mathrm{L}^{-1}\right)$ than Scoat Tarn, but showed the lowest mean annual DOC flux (2.4 $\left.\mathrm{g} \mathrm{DOC} \mathrm{m}^{-2} \mathrm{yr}^{-1}\right)$ as a consequence of significantly lower annual effective precipitation. The three sites with the highest peat and peaty gley cover (i.e. $>0.95 \%$; Beagh's Burn, Loch Tinker (central Scotland) and Troutbeck (northern England) had moderate to high mean concentrations and the three highest DOC fluxes (ranging from 13.5 to $16.8 \mathrm{~g} \mathrm{DOC}^{-2} \mathrm{yr}^{-1}$ ).

Correlation coefficients summarising relationships between long-term mean DOC and long-term mean DOC flux, and a range of explanatory variables included in our analysis are provided in Supplementary Information (Table 2). Relatively few variables showed statistically significant $(\mathrm{p}<0.05)$ relationships with either log DOC or log DOC flux. However, log DOC was particularly strongly (positively) correlated with the percentage cover of wetland soils (PPPG), negatively correlated with effective precipitation $\left(\mathrm{P}_{\mathrm{E}}\right)$ and positively correlated with divalent base cation concentration ([xBC]). Log DOC flux was negatively correlated with altitude (ALT) and positively correlated with mean annual temperature (MAT). A positive correlation with $\log$ chloride concentration $(\log \mathrm{Cl})$ might reflect the strong negative relationship between

$\log \mathrm{Cl}$ and ALT. There were no clear relationships between either DOC or DOC flux and any of the deposition-based predictors, i.e. $\log$ sulphate concentration $\left(\log \left[\mathrm{SO}_{4}\right]\right)$ or estimated reduced, oxidised or total nitrogen deposition. The four sites with the highest log DOC also showed the highest non-marine divalent base cation concentrations, but there was no apparent structure in this relationship for the remaining sites. Scatter plots revealed little covariant structure between potential explanatory variables with the obvious exception of strong negative relationships between altitude and temperature, a negative relationship between altitude and chloride concentration reflecting distance from the coast and hence vulnerability to seasalt deposition, and positive relationships between the sulphate concentration and the three nitrogen deposition variables. 


\section{Final model structure}

The most parsimonious logistic regression model (lowest AIC) for explaining spatial variation in 1992-2011 $\log$ DOC concentration comprised five variables and two interactions representing both physical and chemical determinands and is structured as follows:

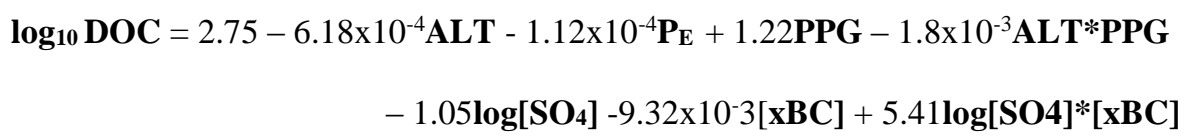

All model terms were highly significant ( $\mathrm{p}=0.001$ or less), and together explained $96.5 \%$ (adjusted $\mathrm{R}^{2}$ ) of the spatial variation in DOC (Table 2). The model included four terms based on three physical parameters: a positive effect of the proportion of peat and peaty gley soil in the catchment (PPPG); negative effects of altitude (ALT) and effective precipitation $\left(\mathrm{P}_{\mathrm{E}}\right)$, and a negative interaction between ALT and PPPG. The combination of these three variables in isolation was sufficient to explain $79 \%$ of the variance in DOC. The final model also included two hydrochemical parameters - negative effects of non-marine base cation concentration $([\mathrm{xBC}])$ and sulphate concentration $\log [\mathrm{SO} 4]$ - and a positive interaction term between the two.

Leave-one-out cross validation of the primary dataset resulted in a very tight relationship between observed and predicted values $\left(\mathrm{R}^{2}=0.92\right)$ and a Root Mean Square Error (RMSE) of $1.06 \mathrm{mg} \mathrm{DOC} \mathrm{L-1}$ (Figure 1). A further independent test of the model, based solely on data obtained from other sites from the mid-1990s, also demonstrated strong predictive power with a single exception. Following the removal of this major outlier (Cottage Hill Syke - a small tributary of the Troutbeck, discussed below), the remaining DOC observations for the sites were strongly correlated with model predictions $\left(R^{2}=0.85, p<0.001\right)$ with a slope of 1.16 and a statistically insignificant intercept of 0.11 (Figure 2).

The structure of the final model has several features in common with previous analyses of spatial determinants of DOC, but the model's overall predictive strength is perhaps unparalleled and provides some 
confidence that DOC draining upland catchments might be predicted over wide spatial scales on the basis of physical catchment characteristics, and estimates of sulphate and divalent base cation leaching.

The same set of predictor variables (but with hydrochemical variables representing 2009-13 means), all again statistically significant, were found to explain a slightly lower proportion of spatial variance (adjusted $\mathrm{R}^{2}=$ 93.7) in mean 2009-2013 DOC concentrations (Table 2b). Coefficients were generally very similar to those in the 1992-2011 baseline model but were $32 \%$ and $57 \%$ smaller for $\log \left[\mathrm{SO}_{4}\right]$ and the $\log [\mathrm{SO} 4] \mathrm{x}[\mathrm{xBC}]$ interaction term respectively (both of which also showed higher $\mathrm{p}$ values). This possibly reflects the greatly reduced spatial variation in sulphate concentration in UK waters in recent years resulting from large reductions in sulphur deposition that have led to a convergence of sulphate concentrations in surface waters nationally (Monteith et al. 2014).

\section{The role of soil type}

The combined proportional cover of the two 'wetland' organic soil types, peats and peaty gleys (PPPG), provided by far the strongest single predictor of log DOC (positive correlation) - a finding that accords with a number of studies from other regions (Aitkenhead et al. 1999; Creed et al. 2008; Dillon and Molot 1997; Hope et al. 1994; Xenopoulos et al. 2003), and in isolation explained $63.2 \%$ of the total spatial variance. While the often highly coloured water draining peatland catchments is sometimes considered a product of the peat itself, analyses of carbon isotopes in DOC draining relatively undisturbed upland UK catchments indicate DOC from these systems is mostly of very recent origin, i.e. <5 years (Evans et al. 2007; Tipping et al. 2010), as has also been found elsewhere (Moore et al. 2013). In this context PPPG would seem to act primarily as an indicator of a) soil anoxia, limiting the respiratory loss of newly deposited/exuded organic matter, and b) the impediment of vertical routing of drainage waters, and consequently of reduced potential for adsorption of DOC by ion-exchange complexes in mineral soil horizons (McDowell and Wood 1984; Moore and Jackson 1989), rather than as a simple indicator of the size of the catchment's terrestrial organic carbon store. It is also feasible the DOC draining peat soils may be more recalcitrant than that draining other soil types (Moody et al. 2013), 
Effective precipitation provided a strong negative effect in the final model. While this is consistent with a net diluting influence on DOC the effect was relatively muted. The model predicts that a four-fold increase in $\mathrm{P}_{\mathrm{E}}$, (i.e. 500 to $2000 \mathrm{~mm}$ ) would reduce DOC concentration by circa $40 \%$. Other influences, including the shift from vertical to more lateral drainage with increasing precipitation - reducing the potential for DOC adsorption by mineral strata, the fact that wetter environments are more likely to be characterised by organic soils, and the effect of precipitation in reducing residence time and hence exposure to photo-mineralisation, may all have partially counteracted the dilution effect.

\section{The role of altitude}

When $\mathrm{P}_{\mathrm{E}}$ is held constant the model predicts that DOC, and hence DOC flux, will increase exponentially with declining altitude (ALT) (Figure 3 - solid black line). Strong negative relationships between DOC and altitude have also been reported widely before (Sobek et al. 2007; Weyhenmeyer and Karlsson 2009; Xenopoulos et al. 2003). While effective as a spatial predictor, from a mechanistic view its inclusion in the model has limited direct explanatory value because a wide range of environmental parameters tend to correlate with altitude (Creed et al. 2008).

Inter-annual variability in total organic carbon concentrations has been shown to be tightly correlated with terrestrial gross primary productivity in waters draining a Scottish peatland (Dinsmore et al. 2013), while field experiments in the northern Pennines have demonstrated a strong temporal correlation between DOC production and net primary production (NPP) as inferred from cumulative solar radiation during the growing season (Harrison et al. 2008). These findings therefore support previous spatial modelling exercises in which effects of altitude on DOC have been linked to primary productivity through: the number of days in the year that mean daily air temperature exceeds $0^{\circ} \mathrm{C}$ (Sweden) (Weyhenmeyer and Karlsson 2009); the number of growing degree days (north-eastern Canada) (Creed et al. 2008); and, the extent of plant cover as inferred by the remotely sensed Normalised Difference Vegetation Index (Norway) (Larsen et al. 2011). However, these spatial studies have not compared the magnitude of the proposed effect of these drivers with the size of the apparent response in DOC. 
In comparison, the influence of temperature (which also declines markedly with increasing altitude) on soil organic matter decomposition rates has been reported widely. The kinetic theory of Arrhenius suggests that organic matter decomposition rates should increase exponentially with increasing temperature, and that decomposition of more recalcitrant substrates, such as the "low quality" organic matter that characterises highly organic soils, will show more sensitive relationships with temperature because of their relatively high activation energies (Davidson and Janssens 2006). In a meta-analysis of 494 studies of soils worldwide, the median relative change in soil respiration rate per $10{ }^{\circ} \mathrm{C}$ rise in temperature (or $\mathrm{Q}_{10}$ ) was 2.39 (Hamdi et al. 2013). However a study of Scottish peats (Chapman and Thurlow 1998), which are likely to be more representative of the organic soils of our calibration sites, reported $\mathrm{Q}_{10}$ values ranging from $2.2-19$, with a mean of 4.8, while a maximum $\mathrm{Q}_{10}$ of 3.53 was observed for peat cores taken from the UK ECN Moor House site under drained conditions (Clark et al. 2009).

In the final model selected here, altitude influences DOC both as a single term and in a positive interaction with PPPG. We first consider its effect in catchments dominated exclusively by better drained soils, i.e. when PPPG $=0$ (and the interaction term is therefore redundant). Here the model shows DOC concentration and flux to increase by a factor of 2.34 over an altitude gradient of 900 - 300 masl - approximately the range covered by the calibration sites and equivalent to a gradient in mean annual air temperature of $4.2-7.9{ }^{\circ} \mathrm{C}$ for a mid-latitude UK site (Figure 3). ECN meteorological data indicates that cumulative solar radiation over the growing season $\left(\mathrm{CSR}_{\mathrm{G}}\right)$ (i.e. the total solar radiation over the months of the year when mean air temperature exceeds $5^{\circ} \mathrm{C}$ ) increases by a factor of 1.45 over the same altitude gradient (Supplementary Information Figure 2). Even if NPP responds proportionally, this alone would be insufficient to explain the observed change in DOC with altitude in organo-mineral soil dominated catchments. However, if the microbial production of DOC from the organic matter pool generated by NPP is temperature dependent, then NPP and temperature dependent decomposition (TDD) might be expected to exert a multiplicative effect. In this case the TDD effect required to explain the modelled change in DOC is given by $2.34 / 1.45=1.62$, equivalent to a $\mathrm{Q}_{10}$ response of 3.7, and therefore broadly consistent with mid-range values reported for Scottish peats (Chapman and Thurlow 1998). Figure 3 demonstrates that the product of $\operatorname{CSR}_{\mathrm{G}}$ and TDD $\left(\mathrm{Q}_{10}=3.7\right)$ changes with altitude in a similar exponential manner to that shown by DOC. However it is likely 
that other altitude-related factors, such as slope, susceptibility to soil freezing, snow accumulation, windspeed effects on plant growth, or microbial cycling of nutrients, also contribute to the overall effect, in which case the effect of temperature alone would not need to be so pronounced.

In contrast to organo-mineral soils, the modelled response of DOC to declining altitude for catchments exclusively covered by wetland soils (i.e. PPPG =100), is far too large to be explained purely by the simple product of NPP and TDD, even if $\mathrm{Q}_{10}$ levels were substantially higher for these soils (Figure 4). The model predicts no difference between catchments for which PPPG $=0$ and PPPG $=1$ at an altitude of 690 masl, but by 300 masl production is almost five times higher from than the latter (Figure 4c). Further mechanisms contributing to this apparent amplification of DOC export may relate to soil hydrological status, and might include: 1) greater accumulation of potentially soluble organic matter carbon in wetland soils; 2) an increase in the ratio of organic matter exported as DOC relative to that being respired as $\mathrm{CO}_{2}$ in wetter environments; and, 3) effects of water table variation in peats (Clark et al. 2009; Fenner and Freeman 2011; Mitchell and McDonald 1992; Toberman et al. 2008) which might be expected to greater at lower altitudes due to lower levels of precipitation and greater evaporation.

Hydrological factors may also account for the significant model underestimate for Cottage Hill Syke catchment, the only major outlier we have encountered to date (Figure 2 - point R). This peat dominated site has by far the smallest catchment (circa 17.4 ha) considered in this study and is heavily gullied. Low $\mathrm{pH}$ and base cation concentration implies very little contribution from groundwater, while the water table remains within $5 \mathrm{~cm}$ of the surface for $83 \%$ of the time (Holden et al. 2012), implying that run-off is likely to be particularly heavily dominated by saturated and overland flow, minimising the potential for retention of DOC by the underlying substrata.

\section{The role of catchment sensitivity to acid deposition}

Despite explaining relatively little of the overall variance in $\log \mathrm{DOC}$ all three hydrochemical terms were highly significant in the full model. A negative effect on DOC of acid deposition, as inferred by $\log \left[\mathrm{SO}_{4}\right]$, dampened by an interactive effect with $[\mathrm{xBC}]$, is consistent with the relationship reported for trends in DOC 
and these variables across a wide range of sites in northern Europe and North America by Monteith et al. (2007). Negative effects of sulphuric acid additions on DOC production in organic and B horizons of soil samples taken from a range of UWMN sites have been shown to be greater in soils with lower base saturation and higher exchangeable aluminium levels (Clark et al. 2009; Palmer et al. 2013). The coefficient for log $\left[\mathrm{SO}_{4}\right]$ is large relative to between-site variation, suggesting DOC is sensitive to even small changes in sulphur deposition. The negative sign for the individual $[\mathrm{xBC}]$ term may reflect the extent to which $\mathrm{DOC}$ in catchment drainage waters interacts with, and is subsequently retained by, mineral soil horizons.

\section{Potential space-for-time implications}

While our spatial model essentially represents "steady state" relationships between DOC and environmental factors, it may also provide some indication of the sensitivity of these systems to future environmental change. Medium emissions climate change scenarios projected by UKCP09 for conditions in 2080 relative to 1961-1990 predict all parts of the UK to become warmer (Murphy et al. 2009). The main temperature increases are forecast for summer, with the greatest increases in mean summer temperatures of $4.2{ }^{\circ} \mathrm{C}$ in southern England, declining to around $2.5{ }^{\circ} \mathrm{C}$ for remoter parts of Scotland. Effects of warming on NPP in the uplands should be most dependent on the rate of advance in spring and retreat in autumn of the temperature threshold for net production to occur, but given the relatively modest response over a considerable altitudinal gradient we show here these effects are unlikely to be substantial. However, a projected increase in annual average temperatures of circa $3{ }^{\circ} \mathrm{C}$ for the UK as a whole (equivalent in temperature terms to a decline in altitude of around $500 \mathrm{~m}$ ), would be sufficient to increase concentrations draining organo-mineral soils on average by circa $150 \%$ relative to current levels if decomposition rates were to respond to temperature at a rate described by a $\mathrm{Q}_{10}$ of 3.7. For the northern and western UK, negligible change is predicted in summer precipitation that dominates the magnitude of wet dry cycling in peats, although a forecast increase in winter precipitation could if anything reduce these fluctuations. The effect of soil type on the magnitude of the relationship between altitude and DOC has potential implications for catchment sensitivity to future warming and thus requires further investigation. Over the 20 year duration of the UWMN to date, however, there have been no clear trends in either air temperature or precipitation, and it should be noted that Zhang et al. (2010) did not detect any change in DOC in lakes in regions of eastern 
Canada that had experienced two decades of warming. Climatic effects on the long-term DOC trend to date are therefore likely to have been small, although effects of inter-annual variability in temperature should be detectable.

For the majority of sites we found relatively good agreement between the relationship between $\log \left[\mathrm{SO}_{4}\right]$ and DOC measured in individual samples at the calibration sites, and the spatially modelled response of DOC to changing $\left[\mathrm{SO}_{4}\right]$, when all other variables (including $\left[\mathrm{xCa}^{2+}+\mathrm{xMg}^{2+}\right]$ ) were held constant (Figure 5). However, relationships for some peatland dominated sites, i.e., River Etherow, Coneyglen Burn and Troutbeck were poor. These sites show a similar curvilinear pattern in the DOC - $\left[\mathrm{SO}_{4}\right]$ relationship in individual samples to the other sites, but the model appears too sensitive to the effect of the $[\mathrm{xBC}] * \log [\mathrm{SO} 4]$ interaction term, which results in a reversal of the net effect of [SO4] at higher base cation concentrations. Further modifications will therefore be necessary to enable prediction of effects of changing deposition on peatland systems. Nevertheless, close agreement for the organo-mineral dominated sites provides further strong support for the hypothesis that reducing acid deposition has dominated the long-term trend in DOC in this region over recent decades (Clark et al. 2010). For these sites the model predicts that the sensitivity of DOC to unit declines in surface water $\left[\mathrm{SO}_{4}\right]$ is increasing as the latter approaches low-to-background levels. Although sulphur deposition has fallen substantially over the last two decades, further, relatively small, reductions are expected according to current national and international emission abatement policy, and are therefore likely to result in further significant increases in DOC at unprecedented rates per unit reduction in the acid load.

Certain factors that have been identified elsewhere as potentially influential appeared to be relatively unimportant in explaining spatial variation in DOC within our dataset. For example, we were unable to detect any systematic differences between sites with significant cover of managed coniferous forest and moorland sites. However, any effects of increased interception of sulphur deposition by forest canopies will have been taken into account by inclusion of the $\log \left[\mathrm{SO}_{4}\right]$ term. Aside from the effects of enhanced deposition, differences in annual inputs of organic matter to the soil, or other factors related to forestry, appear to have not been sufficiently marked at this national scale (and given the substantial effect size of the other controls) 
to exert a significant effect on the model. We were also unable to detect any fertilising influence of nitrogen deposition on DOC. Nitrogen deposition has been identified as a key factor explaining gradients in upland floristic diversity across the UK (Henrys et al. 2011; Stevens et al. 2006) and it has been argued that levels of NPP in the most polluted upland regions will have also been stimulated, with a consequent effect on DOC - an effect that is included in some recent process-based models (Rowe et al. 2014; Tipping et al. 2012). It is possible that nitrogen deposition effects on DOC have been masked by the variable $\log \left[\mathrm{SO}_{4}\right](\mathrm{despite}$ the expectation of opposite effects) as $\mathrm{S}$ and $\mathrm{N}$ deposition are reasonably well correlated spatially. Alternatively it is feasible that NPP in upland catchments throughout the regions covered by our dataset is now effectively $\mathrm{N}$-saturated resulting in no detectable differential effect. Whether recovery from acidification, in conjunction with other intensifying anthropogenic pressures, is resulting in unprecedented levels of DOC or simply reflects a return to pre-industrial levels will require further exploration. 


\section{Acknowledgments}

This study was underpinned by time series data from two long-term monitoring networks, the UK Upland Waters Monitoring Network (UWMN) and the UK Environmental Change Network (ECN) and was supported by the Natural Environment Research Council under the first ERA-EnvHealth call (FP7-ENV2007-CSA-1.2.3-01). We are grateful to all in both networks who who have maintained the excellent standards of data and sample collection and analysis over the year, to David Cooper, Matt Fry, Ron Smith and Chris Curtis for assistance in compiling the explanatory datasets, and to Ed Tipping and Rachel Marshall for comments and suggestions. The UWMN is supported by the UK Department for Environment Food and Rural Affairs (DEFRA), NERC through the Centre for Ecology \& Hydrology (CEH), the Department of the Environment (Northern Ireland), the Environment Agency (EA), the Forestry Commission (FC), Natural Resources Wales (NRW), the Scottish Environmental Protection Agency (SEPA), Scottish Natural Heritage (SNH) and the Welsh Government, the Scottish Government through Marine Scotland Science Pitlochry, Queen Mary University of London and ENSIS Ltd. at the Environmental Change Research Centre, University

College London. We also thank the four anonymous reviewers for their constructive suggestions for improvements to the manuscript. 


\section{References}

Aitkenhead JA, Hope D, Billett MF (1999) The relationship between dissolved organic carbon in stream water and soil organic carbon pools at different spatial scales Hydrol Process 13:1289-1302 doi:10.1002/(sici)1099-1085(19990615)13:8<1289::aid-hyp766>3.0.co;2-m

Battarbee RW, Shilland EM, Kernan M, Monteith DT, Curtis CJ (2014) Recovery of acidified surface waters from acidification in the United Kingdom after twenty years of chemical and biological monitoring (1988-2008) Ecological Indicators 37, Part $\quad$ B:267-273 doi:http://dx.doi.org/10.1016/j.ecolind.2013.10.011

Bauer JE, Bianchi TS (2011) 5.02 - Dissolved Organic Carbon Cycling and Transformation. In: Editors-inChief: Eric W, Donald M (eds) Treatise on Estuarine and Coastal Science. Academic Press, Waltham, pp 7-67. doi:http://dx.doi.org/10.1016/B978-0-12-374711-2.00502-7

Chapman SJ, Thurlow M (1998) Peat respiration at low temperatures Soil Biology and Biochemistry 30:1013-1021 doi:http://dx.doi.org/10.1016/S0038-0717(98)00009-1

Clark JM, Ashley D, Wagner M, Chapman PJ, Lane SN, Evans CD, Heathwaite AL (2009) Increased temperature sensitivity of net DOC production from ombrotrophic peat due to water table drawdown Glob Change Biol 15:794-807 doi:10.1111/j.1365-2486.2008.01683.x

Clark JM et al. (2010) The importance of the relationship between scale and process in understanding longterm DOC dynamics Sci Total Environ 408:2768-2775 doi:10.1016/j.scitotenv.2010.02.046

Cooper DM (2005) Evidence of sulphur and nitrogen deposition signals at the United Kingdom Waters Monitoring Network sites Environ Pollut 137:41-54 doi:10.1016/j.envpol.2004.12.030

Creed IF, Beall FD, Clair TA, Dillon PJ, Hesslein RH (2008) Predicting export of dissolved organic carbon from forested catchments in glaciated landscapes with shallow soils Global Biogeochemical Cycles 22 doi:10.1029/2008gb003294

Curtis CJ, Simpson GL (2014) Trends in bulk deposition of acidity in the UK, 1988-2007, assessed using additive models Ecological Indicators 37, Part $\quad$ B:274-286 doi:http://dx.doi.org/10.1016/j.ecolind.2012.10.023

Davidson EA, Janssens IA (2006) Temperature sensitivity of soil carbon decomposition and feedbacks to climate change Nature 440:165-173 
Dillon PJ, Molot LA (1997) Effect of landscape form on export of dissolved organic carbon, iron, and phosphorus from forested stream catchments Water Resources Research 33:2591-2600 doi:10.1029/97wr01921

Dinsmore KJ, Billett MF, Dyson KE (2013) Temperature and precipitation drive temporal variability in aquatic carbon and GHG concentrations and fluxes in a peatland catchment Glob Change Biol 19:2133-2148 doi:10.1111/gcb.12209

Ekstrom SM, Kritzberg ES, Kleja DB, Larsson N, Nilsson PA, Graneli W, Bergkvist B (2011) Effect of Acid Deposition on Quantity and Quality of Dissolved Organic Matter in Soil-Water Environ Sci Technol 45:4733-4739 doi:10.1021/es104126f

Evans CD et al. (2007) Evidence against recent climate-induced destabilisation of soil carbon from 14C analysis of riverine dissolved organic matter Geophysical Research Letters 34:L07407 doi:10.1029/2007g1029431

Evans CD et al. (2012) Acidity controls on dissolved organic carbon mobility in organic soils Glob Change Biol 18:3317-3331 doi:10.1111/j.1365-2486.2012.02794.x

Evans CD, Monteith DT, Fowler D, Cape JN, Brayshaw S (2011) Hydrochloric Acid: An Overlooked Driver of Environmental Change Environ Sci Technol 45:1887-1894 doi:10.1021/es103574u

Evans CD, Monteith DT, Harriman R (2001) Long-term variability in the deposition of marine ions at west coast sites in the UK Acid Waters Monitoring Network: impacts on surface water chemistry and significance for trend determination Sci Total Environ 265:115-129 doi:10.1016/s00489697(00)00653-7

Evans R (1997) Soil erosion in the UK initiated by grazing animals - A need for a national survey Applied Geography 17:127-141 doi:10.1016/s0143-6228(97)00002-7

Fenner N, Freeman C (2011) Drought-induced carbon loss in peatlands Nature Geosci 4:895-900 doi:http://www.nature.com/ngeo/journal/v4/n12/abs/ngeo1323.html\#supplementary-information

Ferguson P, Lee JA (1983) PAST AND PRESENT SULFUR POLLUTION IN THE SOUTHERN PENNINES Atmospheric Environment 17:1131-1137 doi:10.1016/0004-6981(83)90336-0

Forsberg C (1992) Will an increased greenhouse impact in Fennoscandia give rise to more humic and coloured lakes? In: Salonen K, Kairesalo T, Jones RI (eds) Dissolved Organic Matter in Lacustrine 
Ecosystems, vol 73. Developments in Hydrobiology. Springer Netherlands, pp 51-58. doi:10.1007/978-94-011-2474-4_4

Freeman C, Evans CD, Monteith DT, Reynolds B, Fenner N (2001) Export of organic carbon from peat soils Nature 412:785-785 doi:10.1038/35090628

Gardner M (2008) Long-term proficiency testing for the UK acid waters monitoring network Accredit Qual Assur 13:255-260 doi:10.1007/s00769-008-0367-9

Hamdi S, Moyano F, Sall S, Bernoux M, Chevallier T (2013) Synthesis analysis of the temperature sensitivity of soil respiration from laboratory studies in relation to incubation methods and soil conditions Soil Biology and Biochemistry 58:115-126 doi:http://dx.doi.org/10.1016/j.soilbio.2012.11.012

Harrison AF et al. (2008) Potential effects of climate change on DOC release from three different soil types on the Northern Pennines UK: examination using field manipulation experiments Glob Change Biol 14:687-702 doi:10.1111/j.1365-2486.2007.01504.x

Henrys PA et al. (2011) Impacts of nitrogen deposition on vascular plants in Britain: an analysis of two national observation networks Biogeosciences 8:3501-3518 doi:10.5194/bg-8-3501-2011

Holden J, Gascoign M, Bosanko NR (2007) Erosion and natural revegetation associated with surface land drains in upland peatlands Earth Surface Processes and Landforms 32:1547-1557 doi:10.1002/esp.1476

Holden J, Smart RP, Dinsmore KJ, Baird AJ, Billett MF, Chapman PJ (2012) Natural pipes in blanket peatlands: major point sources for the release of carbon to the aquatic system Glob Change Biol 18:3568-3580 doi:10.1111/gcb.12004

Hope D, Billett MF, Cresser MS (1994) A review of the export of carbon in river water: Fluxes and processes Environ Pollut 84:301-324 doi:http://dx.doi.org/10.1016/0269-7491(94)90142-2

Hruška J, Krám P, McDowell WH, Oulehle F (2009) Increased Dissolved Organic Carbon (DOC) in Central European Streams is Driven by Reductions in Ionic Strength Rather than Climate Change or Decreasing Acidity Environmental Science \& Technology 43:4320-4326 doi:10.1021/es803645w

Larsen S, Andersen T, Hessen DO (2011) Predicting organic carbon in lakes from climate drivers and catchment properties Global Biogeochemical Cycles 25:GB3007 doi:10.1029/2010gb003908 
McDowell WH, Wood T (1984) Podzolization: Soil Processes Control Dissolved Organic Carbon Concentrations in Stream Water Soil Sci 137:23-32

Mitchell G, McDonald AT (1992) Discolouration of water by peat following induced drought and rainfall simulation Water Research 26:321-326 doi:http://dx.doi.org/10.1016/0043-1354(92)90029-4

Monteith DT, Evans CD, Henrys PA, Simpson GL, Malcolm IA (2014) Trends in the hydrochemistry of acid-sensitive surface waters in the UK 1988-2008 Ecological Indicators 37, Part B:287-303 doi:http://dx.doi.org/10.1016/j.ecolind.2012.08.013

Monteith DT et al. (2007) Dissolved organic carbon trends resulting from changes in atmospheric deposition chemistry Nature 450:537-U539 doi:10.1038/nature06316

Moody CS, Worrall F, Evans CD, Jones TG (2013) The rate of loss of dissolved organic carbon (DOC)

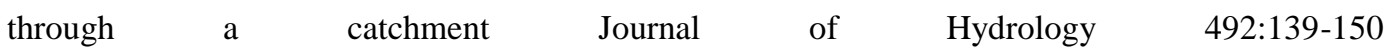
doi:http://dx.doi.org/10.1016/j.jhydrol.2013.03.016

Moore S et al. (2013) Deep instability of deforested tropical peatlands revealed by fluvial organic carbon fluxes Nature 493:660-663 doi:http://www.nature.com/nature/journal/v493/n7434/abs/nature11818.html\#supplementaryinformation

Moore TR, Jackson RJ (1989) Dynamics of dissolved organic carbon in forested and disturbed catchments, Westland, New Zealand: 2. Larry River Water Resources Research 25:1331-1339 doi:10.1029/WR025i006p01331

Murphy JM et al. (2009) UK Climate Projections Science Report: Climate change projections. . Met Office Hadley Centre, Exeter.,

Oulehle F, Hruska J (2009) Rising trends of dissolved organic matter in drinking-water reservoirs as a result of recovery from acidification in the Ore Mts., Czech Republic Environmental pollution (Barking, Essex : 1987) 157:3433-3439 doi:10.1016/j.envpol.2009.06.020

Palmer SM, Clark JM, Chapman PJ, van der Heijden GMF, Bottrell SH (2013) Effects of acid sulphate on DOC release in mineral soils: the influence of SO42- retention and Al release Eur J Soil Sci 64:537544 doi:10.1111/ejss. 12048 
Rosén P, Bindler R, Korsman T, Mighall T, Bishop K (2011) The complementary power of pH and lakewater organic carbon reconstructions for discerning the influences on surface waters across decadal to millennial time scales Biogeosciences 8:2717-2727 doi:10.5194/bg-8-2717-2011

RoTAP (2012) Review of Transboundary Air Pollution in the UK. Acidification, Eutrophication, Ground Level Ozone and Heavy Metals in the UK. .

Rowe EC et al. (2014) Predicting nitrogen and acidity effects on long-term dynamics of dissolved organic matter Environ Pollut 184:271-282 doi:http://dx.doi.org/10.1016/j.envpol.2013.08.023

SCAMP (2013) United Utilities. SCAMP Monitoring - key messages. . Penny Anderson Associates Limited,

Skjelkvåle BL et al. (2005) Regional scale evidence for improvements in surface water chemistry 1990-2001 Environ Pollut 137:165-176 doi:10.1016/j.envpol.2004.12.023

Smith R, Fowler D (2001) Uncertainty in Estimation of Wet Deposition of Sulphur Water, Air, \& Soil Pollution: Focus 1:341-353 doi:10.1023/a:1013144231312

Smith RI, Fowler D, Sutton MA, Flechard C, Coyle M (2000) Regional estimation of pollutant gas dry deposition in the UK: model description, sensitivity analyses and outputs Atmospheric Environment 34:3757-3777 doi:10.1016/s1352-2310(99)00517-8

Sobek S, Tranvik LJ, Prairie YT, Kortelainen P, Cole JJ (2007) Patterns and regulation of dissolved organic carbon: An analysis of 7,500 widely distributed lakes Limnol Oceanogr 52

Stevens CJ, Dise NB, Gowing DJG, Mountford JO (2006) Loss of forb diversity in relation to nitrogen deposition in the UK: regional trends and potential controls Glob Change Biol 12:1823-1833

Taylor PG, Townsend AR (2010) Stoichiometric control of organic carbon-nitrate relationships from soils to

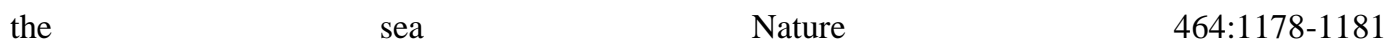
doi:http://www.nature.com/nature/journal/v464/n7292/suppinfo/nature08985_S1.html

Thurman EM (1985) Organic Geochemistry of Natural Waters. Martinus Nijho $\square /$ Dr W. Junk Publishers, Dor-

drecht, The Netherlands

Tipping E, Billett MF, Bryant CL, Buckingham S, Thacker SA (2010) Sources and ages of dissolved organic matter in peatland streams: evidence from chemistry mixture modelling and radiocarbon data Biogeochemistry 100:121-137 doi:10.1007/s10533-010-9409-6 
Tipping E, Rowe EC, Evans CD, Mills RTE, Emmett BA, Chaplow JS, Hall JR (2012) N14C: A plant-soil nitrogen and carbon cycling model to simulate terrestrial ecosystem responses to atmospheric $\begin{array}{llll}\text { nitrogen } & \text { deposition } & \text { Ecological } & \text { Modelling }\end{array}$ doi:http://dx.doi.org/10.1016/j.ecolmodel.2012.08.002

Toberman H, Evans CD, Freeman C, Fenner N, White M, Emmett BA, Artz RRE (2008) Summer drought effects upon soil and litter extracellular phenol oxidase activity and soluble carbon release in an upland Calluna heathland Soil Biology and Biochemistry 40:1519-1532 doi:http://dx.doi.org/10.1016/j.soilbio.2008.01.004

Vrba J et al. (2003) Long-term studies (1871-2000) on acidification and recovery of lakes in the Bohemian Forest (central Europe) Science of The Total Environment 310:73-85 doi:http://dx.doi.org/10.1016/S0048-9697(02)00624-1

Weyhenmeyer GA, Karlsson J (2009) Nonlinear response of dissolved organic carbon concentrations in boreal lakes to increasing temperatures Limnology and Oceanography 54:2513-2519 doi:10.4319/lo.2009.54.6_part_2.2513

Xenopoulos MA, Lodge DM, Frentress J, Kreps TA, Bridgham SD, Grossman E, Jackson CJ (2003) Regional comparisons of watershed determinants of dissolved organic carbon in temperate lakes from the Upper Great Lakes region and selected regions globally Limnology and Oceanography 48:23212334 doi:10.4319/1o.2003.48.6.2321

Yallop AR, Clutterbuck B (2009) Land management as a factor controlling dissolved organic carbon release from upland peat soils 1: Spatial variation in DOC productivity Sci Total Environ 407:3803-3813 doi:10.1016/j.scitotenv.2009.03.012

Zhang J et al. (2010) Long-term patterns of dissolved organic carbon in lakes across eastern Canada: Evidence of a pronounced climate effect Limnology and Oceanography 55:30-42 doi:10.4319/lo.2010.55.1.0030 
Table 1. Physical parameters and mean annual DOC data for the study sites.

\begin{tabular}{|c|c|c|c|c|c|c|c|c|}
\hline Site no. & Site & latitude & longitude & $\begin{array}{l}\text { Mean } \\
\text { catchment } \\
\text { altitude } \\
\text { (masl) } \\
\end{array}$ & $\begin{array}{l}\text { modelled mean } \\
\text { annual } \\
\text { temperature } \\
\left({ }^{\circ} \mathrm{C}\right) \\
\end{array}$ & $\begin{array}{l}\text { modelled } \\
\text { effective } \\
\text { precipitation } \\
\left(\mathrm{mm} \mathrm{yr}^{-1}\right)\end{array}$ & $\begin{array}{l}\text { DOC } \\
\text { concentration } \\
(1992-2011) \\
\left(\mathrm{mg} \mathrm{L}^{-1}\right) \\
\end{array}$ & $\begin{array}{l}\text { modelled DOC flux } \\
(\mathrm{g} \mathrm{m}-2 \mathrm{yr}-1)\end{array}$ \\
\hline 1 & Loch Coire nan Arr & 57.4171 & -5.65186 & 446 & 6.08 & 2838 & 3.0 & 8.5 \\
\hline 2 & Allt a'Mharcaidh & 57.1178 & -3.84959 & 706 & 4.59 & 773 & 3.2 & 2.4 \\
\hline 3 & Allt na Coire nan Con & 56.7584 & -5.61215 & 333 & 6.99 & 2262 & 5.6 & 12.7 \\
\hline 4 & Lochnagar & 56.9583 & -3.23157 & 914 & 3.37 & 1295 & 1.8 & 2.4 \\
\hline 5 & Loch Chon & 56.2122 & -4.54755 & 275 & 7.54 & 2099 & 4.9 & 10.3 \\
\hline 6 & Loch Tinker & 56.2282 & -4.5099 & 469 & 6.35 & 2179 & 6.2 & 13.5 \\
\hline 7 & Round Loch of Glenhead & 55.0937 & -4.43045 & 377 & 7.30 & 2014 & 4.1 & 8.2 \\
\hline 8 & Loch Grannoch & 55.0031 & -4.28109 & 318 & 7.69 & 2050 & 6.1 & 12.5 \\
\hline 9 & Dargall Lane Burn & 55.0775 & -4.43103 & 416 & 7.06 & 2156 & 2.3 & 5.0 \\
\hline 10 & Scoat Tarn & 54.482 & -3.29955 & 717 & 5.43 & 2914 & 1.6 & 4.6 \\
\hline 11 & Burnmoor Tarn & 54.4285 & -3.25931 & 329 & 7.82 & 1676 & 3.0 & 5.0 \\
\hline 12 & River Etherow & 53.493 & -1.82663 & 480 & 7.21 & 1087 & 8.2 & 8.9 \\
\hline 15 & Llyn Llagi & 53.0149 & -4.0153 & 549 & 6.95 & 2420 & 3.0 & 7.4 \\
\hline 16 & Llyn Cwm Mynach & 52.7955 & -3.96212 & 360 & 8.19 & 1815 & 2.6 & 4.8 \\
\hline 17 & Afon Hafren & 52.4741 & -3.70337 & 527 & 7.28 & 2142 & 2.5 & 5.3 \\
\hline 18 & Afon Gwy & 52.4542 & -3.70555 & 558 & 7.10 & 2136 & 2.5 & 5.3 \\
\hline 19 & Beaghs Burn & 55.1005 & -6.16357 & 332 & 7.57 & 1210 & 13.9 & 16.9 \\
\hline 20 & Bencrom River & 54.1573 & -6.00503 & 422 & 7.34 & 1358 & 5.4 & 7.3 \\
\hline 21 & Blue Lough & 54.1585 & -5.96976 & 459 & 7.12 & 1236 & 4.8 & 5.9 \\
\hline 22 & Coneyglen Burn & 54.7393 & -7.00599 & 360 & 7.52 & 1120 & 10.5 & 11.8 \\
\hline 30 & Troutbeck & 54.695 & -2.38784 & 600 & 6.07 & 1434 & 9.8 & 14.0 \\
\hline
\end{tabular}


Table 2a Multivariate logistic regression model statistics for the most parsimonious (lowest AIC) model explaining spatial variation in $\log _{10} 20$ year $(1992-2011)$ mean DOC concentration.

\begin{tabular}{|c|c|c|c|}
\hline Predictor & Coefficient & SE Coefficient & $P$ value \\
\hline Constant & 2.747 & 0.378 & $<0.001$ \\
\hline Altitude(m) (ALT) & -0.00062 & 0.0001 & $<0.001$ \\
\hline Effective precipitation $(\mathrm{mm})(\mathbf{P E})$ & -0.000112 & 0.000024 & 0.001 \\
\hline Proportion peat + peaty gley soil (PPPG) & 1.217 & 0.158 & $<0.001$ \\
\hline ALT * PPPG & -0.00182 & 0.00035 & $<0.001$ \\
\hline $\log \left[\right.$ sulphate] $\left(\mu \mathrm{eq} \mathrm{L} \mathrm{L}^{-1}\right)(\log [\mathbf{S O 4}])$ & -1.051 & 0.186 & $<0.001$ \\
\hline [Non-marine divalent base cation] $\left(\mu \mathrm{eq} \mathrm{L} \mathrm{L}^{-1}\right)([\mathbf{x B C}])$ & -0.0093 & 0.0021 & 0.001 \\
\hline \multirow[t]{2}{*}{$\log [\mathrm{SO} 4] *[\mathrm{xBC}]$} & 0.00542 & 0.0011 & $<0.001$ \\
\hline & $\mathrm{R}^{2}=97$ & $\begin{array}{l}\mathrm{S}=0.0488 \\
.7 \% \quad \text { Adjusted } \mathrm{R}^{2}=96.5\end{array}$ & \\
\hline
\end{tabular}

Table 2b Multivariate logistic regression model statistics explaining spatial variation in $\log _{10}$ DOC concentration for the period 2009-2013 based on the same parameters selected for the most parsimonious model (see Table 2a). Note data for Loch Coire nan Arr, monitoring of which ceased in 2007, has been replaced with data for nearby Loch Coire Fionnaraich.

\begin{tabular}{|l|r|r|r|}
\hline Predictor & Coefficient & SE Coefficient & P value \\
\hline Constant & 2.089 & 0.371 & $<0.001$ \\
\hline Altitude(m) (ALT) & -0.00053 & 0.0001 & $<0.001$ \\
\hline Effective precipitation (mm) (PE) & -0.000091 & 0.00003 & 0.010 \\
\hline Proportion peat + peaty gley soil (PPPG) & 1.126 & 0.218 & $<0.001$ \\
\hline ALT * PPPG & -0.00172 & 0.00047 & 0.003 \\
\hline $\log \left[\right.$ sulphate] $\left(\mu \mathrm{eq} \mathrm{L}^{-1}\right)(\mathbf{l o g}[\mathbf{S O 4}])$ & -0.715 & 0.181 & 0.002 \\
\hline$\left[\right.$ Non-marine divalent base cation] $\left(\mu \mathrm{eq} \mathrm{L}^{-1}\right)[\mathbf{x B C}]$ & -0.0040 & 0.0012 & 0.006 \\
\hline Log[SO4] * [xBC] & 0.00629 & 0.0022 & 0.013 \\
\hline \multicolumn{2}{|c|}{ S $=0.0632$} \\
\hline
\end{tabular}


Figure Legends

Figure 1 Comparison of long term observed mean annual DOC concentration of UWMN/ECN sites and predicted DOC concentration based on leave-one out cross validation. Site numbers according to Table 1. 1:1 line = feint grey; linear regression line $=$ black

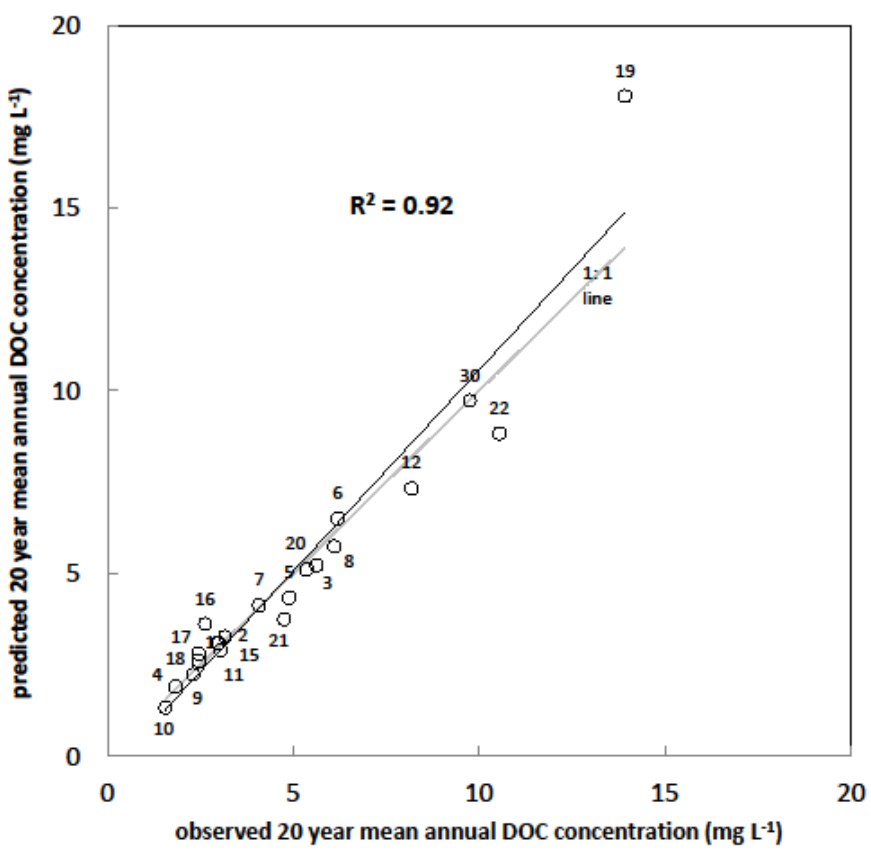


Figure 2 Relationship between measured mean DOC concentrations for upland lake and stream sites in Scotland and Wales (sampled repeatedly over the course of one year only during the early-mid 1990s) and concentrations predicted by the final model on the basis of long-term modelled effective precipitation, mean catchment altitude, proportion of peat and peaty gley soil in terrestrial catchment, and mean sulphate and non-marine divalent base cation concentration for the year of sampling. A list of sites and locations are provided in Supplementary Information (Table 3) .

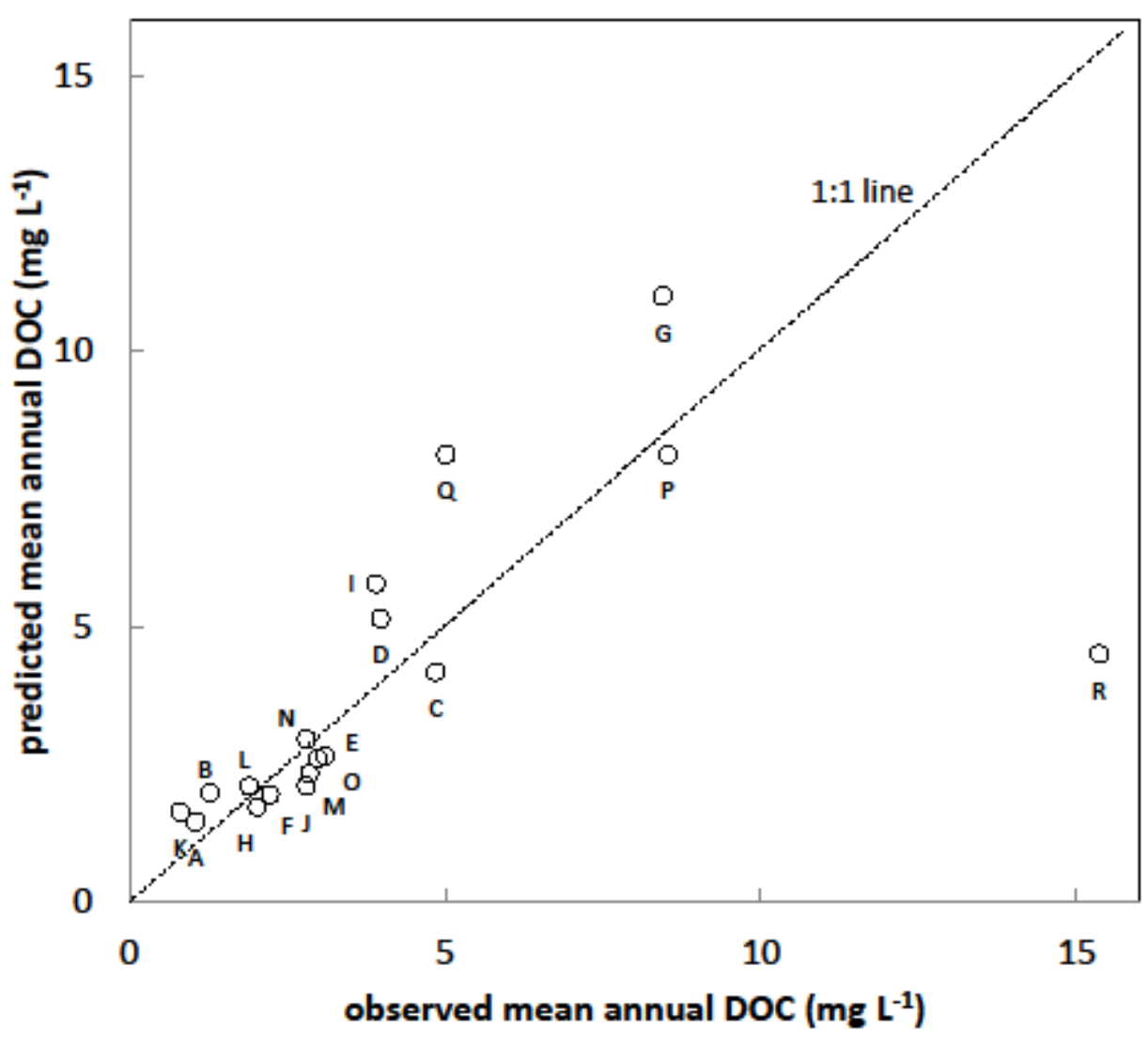


Figure 3 Modelled effect of altitude on DOC concentration, or flux, for UK upland catchments devoid of peats or peaty gley soils, relative to levels at 900 masl (solid line). Other lines represent: the modelled effects of altitude on cumulative growing season solar radiation over the growing season $\left(\mathrm{CSR}_{\mathrm{G}}\right)$, assumed to be a surrogate for net primary production (filled squares); modelled temperature dependent decomposition (TDD) assuming a $\mathrm{Q}_{10}$ of 3.7 (empty squares); and, the product of the above effects of $\mathrm{CSR}_{\mathrm{G}}$ and TDD (dotted line).

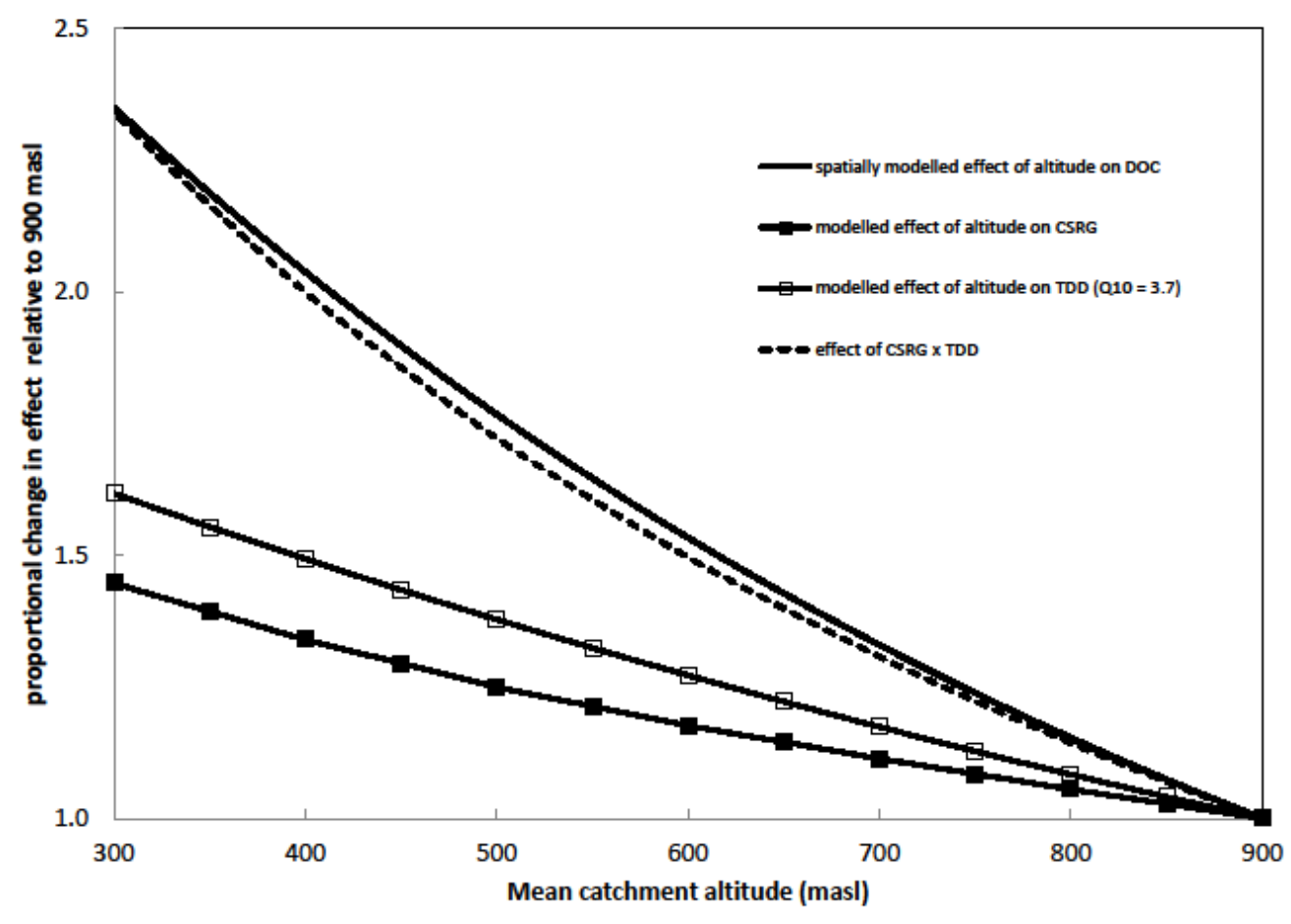


Figure 4 a-b) Modelled change in DOC concentration with altitude for hypothetical sets of sites representing peat or peaty gley dominated catchments (black lines) and other upland soil types (grey lines). a) poorly buffered and acidified sites with rainfall, and sulphate and non-marine divalent cation concentration equivalent to the Round Loch of Glenhead in Galloway. b) strongly buffered non-acidified sites with rainfall, and sulphate and non-marine divalent cation concentration equivalent to the Trout Beck in the northern Pennines. c) The effect of altitude on the ratio of concentrations between the two soil type end-members (i.e. $\mathrm{PPPG}=1$ : $\mathrm{PPPG}=0$ ) regardless of other factors. Dotted line = unity.

a)

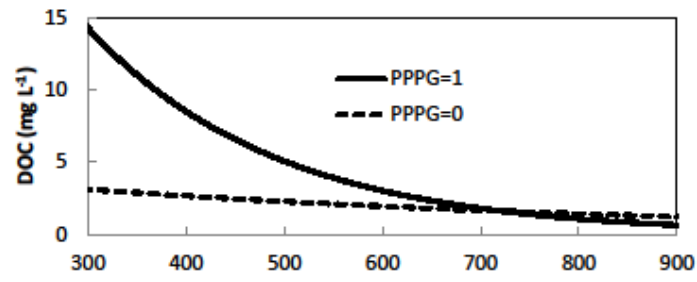

b)

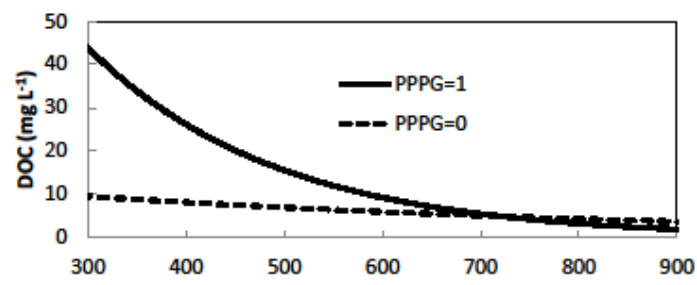

c)

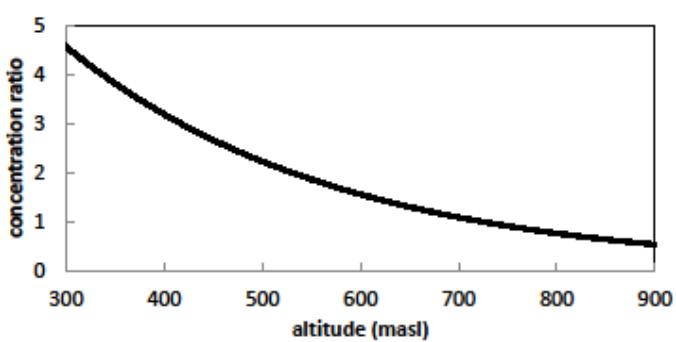




\section{Figure 5}

Change in mean DOC concentration ( $\left.\mathrm{mg} \mathrm{L}^{-1}\right)$ with changing sulphate concentration $\left(\mu \mathrm{eq} \mathrm{L}^{-1}\right)$ at the study sites estimated by the final model with all other parameters held constant (line), superimposed on a scatter plot of DOC concentration against sulphate concentration in individual water samples taken from these sites over the last two decades.
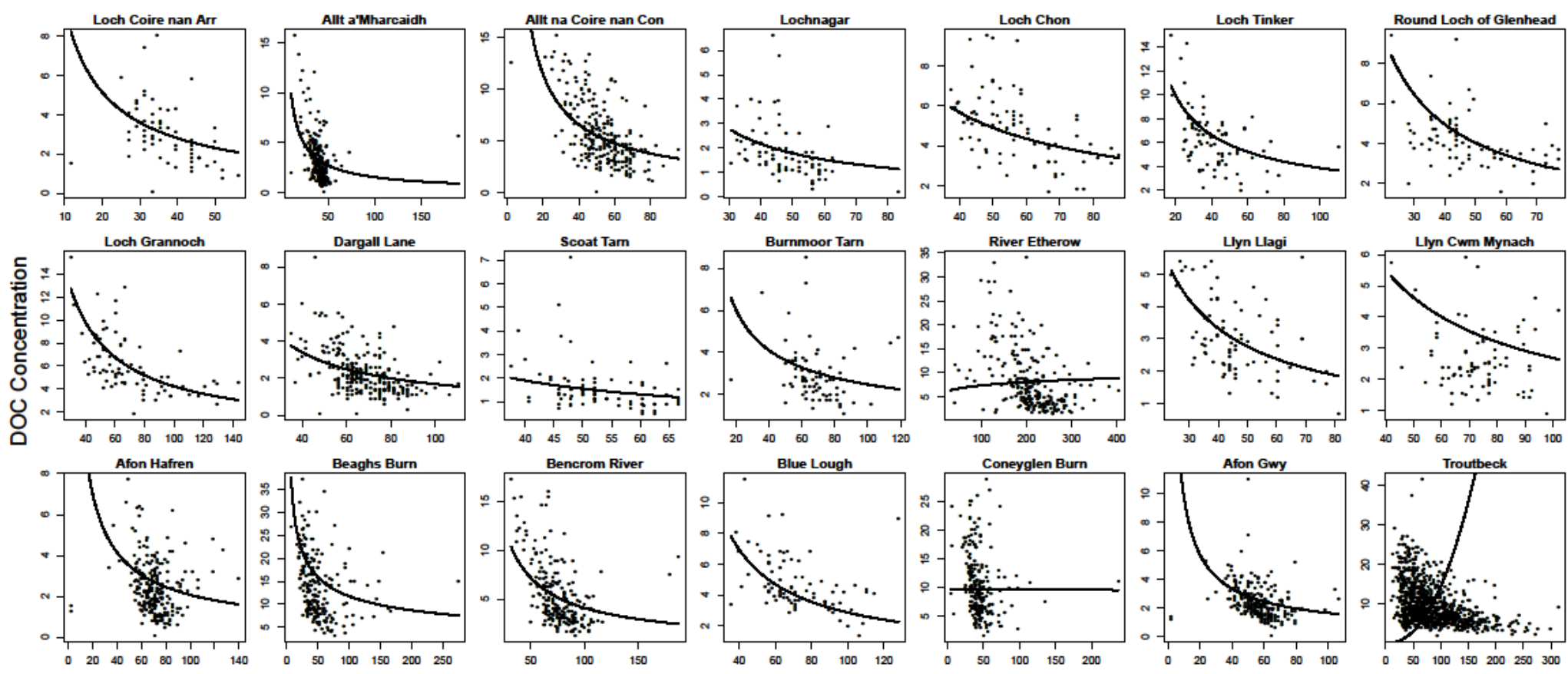

$\mathrm{SO}_{4}^{-2}$

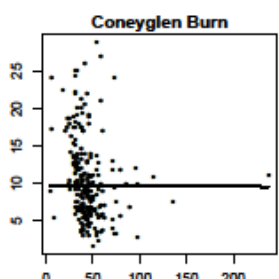

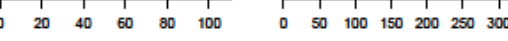




\section{Supplementary Information Table 1}

Variables included within candidate multivariate logistic regression models to explain spatial variability in long-term mean dissolved organic carbon concentration.

\begin{tabular}{|c|c|c|}
\hline Variable & Abbreviation & Units \\
\hline $\begin{array}{l}\log _{10} \text { Mean annual DOC } \\
\text { concentration }\end{array}$ & {$[\mathrm{DOC}]$} & $\mathrm{mg} \mathrm{CL}^{-1}$ \\
\hline $\log _{10}$ Mean annual DOC flux & DOC flux & $\mathrm{gC} \mathrm{m}^{-2} \mathrm{yr}^{-1}$ \\
\hline Altitude & ALT & Metres above sea level \\
\hline $\begin{array}{l}\text { Total annual effective } \\
\text { precipitation }\end{array}$ & $P_{E}$ & $\mathrm{Mm} \mathrm{yr}^{-1}$ \\
\hline Mean annual temperature & MAT & ${ }^{\circ} \mathrm{C}$ \\
\hline $\begin{array}{l}\text { Mean annual reduced nitrogen } \\
\text { deposition ( } 5 \mathrm{~km} \text { resolution) }\end{array}$ & RED_N_DEP & keq ha ${ }^{-1} \mathrm{yr}^{-1}$ \\
\hline $\begin{array}{l}\text { Mean annual oxidised nitrogen } \\
\text { deposition ( } 5 \mathrm{~km} \text { resolution) }\end{array}$ & OX_N_DEP & keq ha ${ }^{-1} \mathrm{yr}^{-1}$ \\
\hline $\begin{array}{l}\text { Total annual nitrogen } \\
\text { deposition ( } 5 \mathrm{~km} \text { resolution) }\end{array}$ & TOT_N_DEP & \\
\hline $\begin{array}{l}\text { Mean annual sulphur } \\
\text { deposition ( } 5 \mathrm{~km} \text { resolution) }\end{array}$ & S_DEP & keq ha ${ }^{-1} \mathrm{yr}^{-1}$ \\
\hline $\begin{array}{l}\% \text { of catchments covered by } \\
\text { coniferous forestry }\end{array}$ & \%FOREST & $\%$ \\
\hline $\begin{array}{l}\text { Proportion of catchment } \\
\text { occupied by brown podsolic } \\
\text { soils }\end{array}$ & BPS & proportion \\
\hline $\begin{array}{l}\text { Proportion of catchment } \\
\text { occupied by Gley podsols }\end{array}$ & GP & proportion \\
\hline $\begin{array}{l}\text { Proportion of catchment } \\
\text { occupied by humic-sandy gley } \\
\text { soils }\end{array}$ & HSG & proportion \\
\hline $\begin{array}{l}\text { Proportion of catchment } \\
\text { occupied by Peat soils }\end{array}$ & PEAT & proportion \\
\hline $\begin{array}{l}\text { Proportion of catchment } \\
\text { occupied by Podsols }\end{array}$ & POD & proportion \\
\hline $\begin{array}{l}\text { Proportion of catchment } \\
\text { occupied by Rankers }\end{array}$ & RANK & proportion \\
\hline $\begin{array}{l}\text { Proportion of catchment } \\
\text { occupied by Sandy gley soils }\end{array}$ & SG & proportion \\
\hline $\begin{array}{l}\text { Proportion of catchment } \\
\text { occupied by peaty gley soils }\end{array}$ & $P G$ & proportion \\
\hline $\begin{array}{l}\text { Proportion of catchment } \\
\text { occupied by Stagnopodsols }\end{array}$ & SP & proportion \\
\hline $\begin{array}{l}\text { Proportion of catchment } \\
\text { occupied by peat }+ \text { peaty gley } \\
\text { soil }\end{array}$ & PPPG & proportion \\
\hline $\begin{array}{l}\log _{10} \text { Mean annual sulphate } \\
\text { concentration }\end{array}$ & $\log \left[\mathrm{SO}_{4}\right]$ & $\mu e q \mathrm{~L}^{-1}$ \\
\hline $\begin{array}{l}\text { Divalent non-marine base } \\
\text { cation concentration }\end{array}$ & {$[\mathrm{xBC}]$} & $\mu e q \mathrm{~L}^{-1}$ \\
\hline
\end{tabular}


Supplementary Information Figure 1. Seasonal variation in mean monthly air temperature and mean monthly solar radiation measured at Environmental Change Network terrestrial monitoring sites. Solar radiation curves (yellow) fitted using a sin function with peak centred on the summer solstice. Air temperature curves fitted using a GAM function. Horizontal grey lines correspond with an air temperature of $5{ }^{\circ} \mathrm{C}$. Vertical grey lines provide period of year air temperature exceeds $5^{\circ} \mathrm{C}$ and primary production is assumed to occur. Integration of the area between the the pairs of vertical grey lines, bounded by the solar radiation curve provides the cumulative annual solar radiation over the hypothetical growing season (CSRG). 

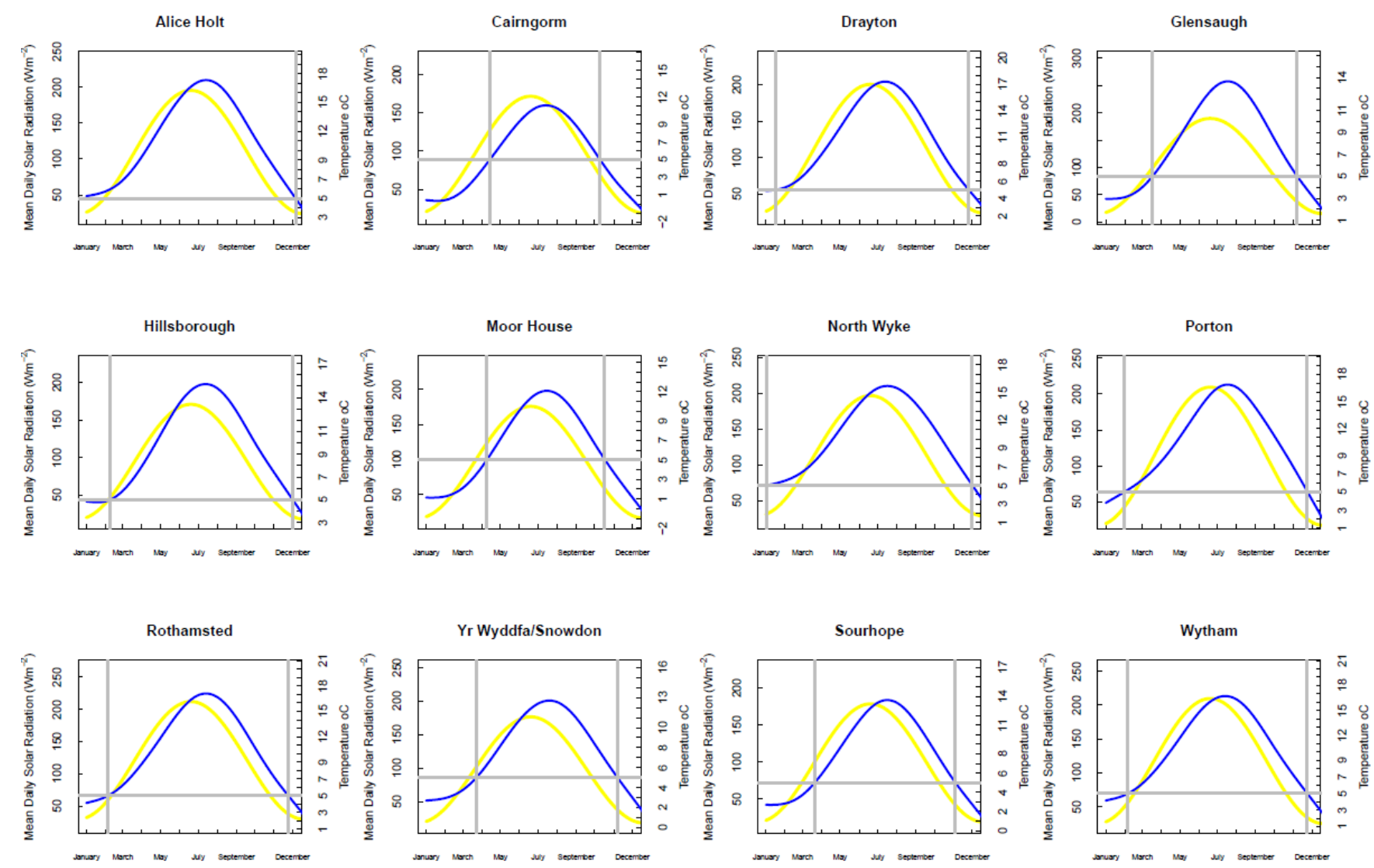

\section{Supplementary Information Figure 2.}

Relationship between modelled cumulative solar radiation over the growing season $\left(\mathrm{CSR}_{\mathrm{G}}\right)$ and the altitude of Environmental Change Network meteorological stations. A GAM function (blue line), is used to represent the response of CSRG to changing altitude in the Discussion section. 


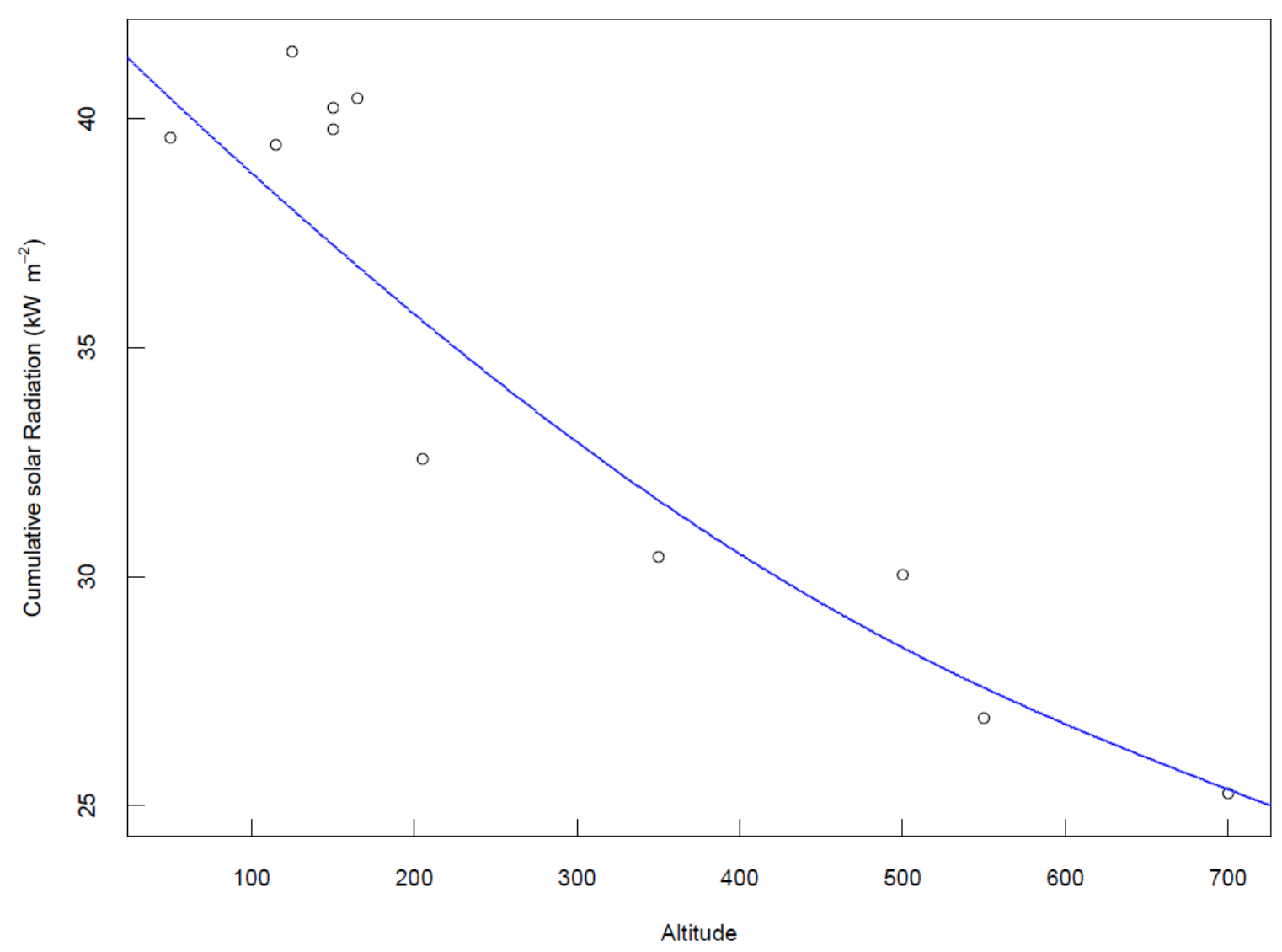

